\title{
Analisis Portofolio Optimal Saham Syariah Jakarta Islamic Index (JII) Periode 2015-2017
}

\section{Optimal Portfolio Analysis of the Jakarta Islamic Index (JII) Shariah Stock for the 2015-2017 Period}

\author{
Derry Permata Sari* \\ Program Studi Magister Manajemen, Fakultas Ekonomi, Universitas Andalas, Padang 25163 \\ e-mail: p.sderry18@gmail.com \\ Rindah Febriana Suryawati \\ Departemen Manajemen, Fakultas Ekonomi dan Manajemen, IPB University, Dramaga, Bogor 16680 \\ e-mail: rindah.suryawati@gmail.com
}

\begin{abstract}
Trend of stock investment in Sharia Stock Market has been rising from 2015-2017. This trend must be followed by a comprehensive understanding of investors in choosing a profitable stock combination by considering a measurable risk and rates of return. This research aims to identify optimal sharia portfolio theory of Markowitz. Model with the lowest preference risk, Markowitz Model with optimal sharpe ratio, and Single Index Model. The analysis then aims to compare expected return and portfolio risk levels formed from the three models, and to provide optimal portfolio recommendations to investors that can be used as consideration of decision making in investing in sharia Jakarta Islamic Index. This research uses reports of daily stock price, dividend, IHSG, and sukuk. The eighteen object in this research were obtained from a purposive sampling method. Based on the calculation, optimal portfolio was obtained using Markowitz model with optimal Sharpe ratio which resulted in the best combination of stock with expected rate of return and risk level of 33,74 percent and 22 percent in a year.
\end{abstract}

Keyword: markowitz model, single index model, sharpe ratio, optimal portfolio.

\begin{abstract}
ABSTRAK
Tren investasi di pasar saham syariah Indonesia mengalami peningkatan dari tahun 2015 sampai dengan 2017. Peningkatan ini juga harus diimbangi dengan sikap investor yang mampu memilih kombinasi saham terbaik dengan tingkat pengembalian dan risiko yang terukur melalui portofolio optimal. Tujuan penelitian ini adalah untuk menghitung portofolio optimal saham syariah Jakarta Islamic Index menggunakan Model Markowitz dengan preferensi risiko terendah, Model Markowitz dengan sharpe ratio optimal, dan Single Index Model. Analisis kemudian dilakukan untuk membandingkan tingkat pengembalian yang diharapkan dan tingkat risiko portofolio yang terbentuk dari model tersebut, dan memberikan rekomendasi portofolio optimal kepada investor yang dapat dijadikan sebagai bahan pertimbangan pengambilan keputusan dalam berinvestasi pada saham syariah Jakarta Islamic Index. Penelitian ini menggunakan data harga saham harian, data dividen, IHSG, dan data sukuk. Pemilihan 18 objek saham diperoleh dengan menggunakan metode purposive sampling. Berdasarkan hasil perhitungan, portofolio optimal diperoleh menggunakan model Markowitz dengan sharpe ratio optimal yang menghasilkan kombinasi saham terbaik dengan tingkat pengembalian yang diharapkan dan tingkat risiko sebesar 33,74 persen dan 22 persen dalam setahun.
\end{abstract}

Kata kunci: model markowitz, single index model, sharpe ratio, portofolio optimal. 


\section{PENDAHULUAN}

Tren investasi di pasar modal saham syariah mengalami peningkatan selama kurun waktu tiga tahun terakhir. Hal ini dipengaruhi oleh perubahan gaya hidup dan tingkat kesadaran masyarakat Indonesia terhadap pentingnya penerapan prinsip syariah dalam berinvestasi. Menurut Hidayat (2011), saham syariah merupakan surat bukti atau tanda kepemilikan modal pada perusahaan yang jenis usaha, akad, produk barang dan jasa yang diberikan, serta pengelolaannya tidak bertentangan dengan prinsip syariah, sehingga bisa disimpulkan pengelolaan saham syariah meliputi keseluruhan aspek saham berdasarkan hukum Islam. Saham syariah dinilai sebagai jenis saham yang memiliki daya tarik positif karena mampu memberikan keuntungan yang lebih baik dan adil sesuai dengan prinsip Islam. Emiten yang sudah mendaftarkan sahamnya kedalam Daftar Efek Syariah (DES) mengalami perkembangan tiap tahunnya. Saham-saham yang terdapat dalam DES ditinjau setiap enam bulan sekali yaitu pada bulan Mei dan November. Sampai dengan Desember 2017, saham syariah yang tercatat berjumlah 382 saham. Data perkembangan jumlah saham syariah dalam Daftar Efek Syariah (DES) periode 2015-2017 terdapat pada Gambar 1.

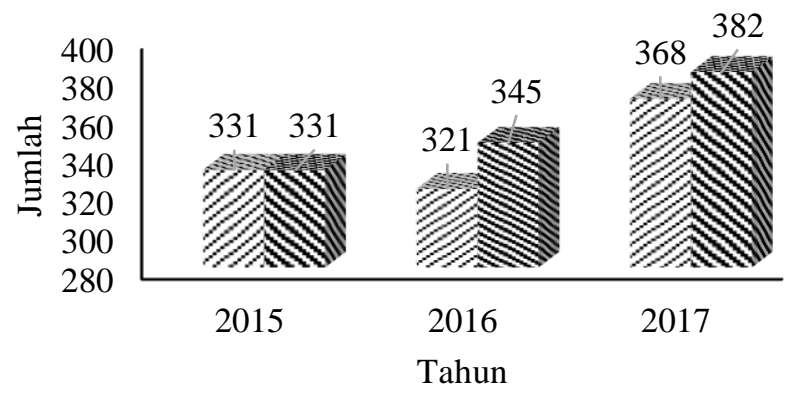

$\$$ Periode $1 \not$ Periode 2

Gambar 1. Perkembangan jumlah saham syariah dalam DES Sumber: Otoritas Jasa Keuangan (2017)

Indonesia menerapkan dua indeks saham syariah sebagai tolok ukur pergerakan harga saham syariah yaitu Jakarta Islamic Index (JII) dan Indonesia Sharia Stock Index (ISSI). Kedua kelompok saham syariah tersebut merupakan saham yang terdaftar di Bursa Efek Indonesia (BEI). ISSI merupakan indeks saham yang mencerminkan keseluruhan saham syariah yang tercatat di BEI dan terdaftar dalam Daftar Efek Syariah (DES). Sedangkan JII lebih spesifik dari ISSI, karena pada saham JII hanya terdapat 30 saham syariah yang memiliki rata-rata kapitalisasi terbesar dan tingkat likuiditas terbesar. Nilai kapitalisasi pasar saham syariah dari tahun 2015 sampai tahun 2017 disajikan pada Gambar 2.

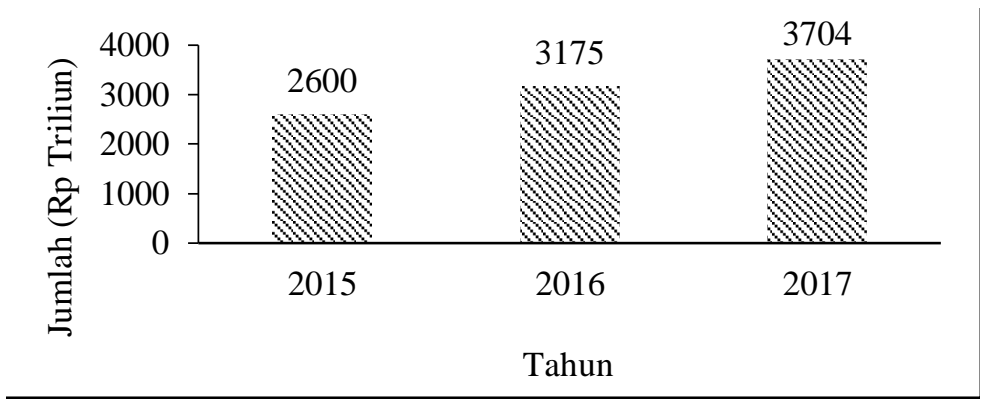

Gambar 2. Kapitalisasi pasar saham syariah Indonesia Sumber: Otoritas Jasa Keuangan (2017) 
Terjadinya peningkatan nilai kapitalisasi pasar saham syariah di Indonesia dari tahun 2015 sampai tahun 2017 yaitu sebesar 22 persen dari tahun 2015 ke tahun 2016 dan 17 persen dari tahun 2016 ke Tahun 2017. Peningkatan nilai kapitalisasi pasar ini menggambarkan semakin tertariknya investor untuk berinvestasi di saham syariah. Sedangkan nilai kapitalisasi pasar Jakarta Islamic Index (JII) yang dicatat oleh Bursa Efek Indonesia yang terdapat pada Gambar 3.

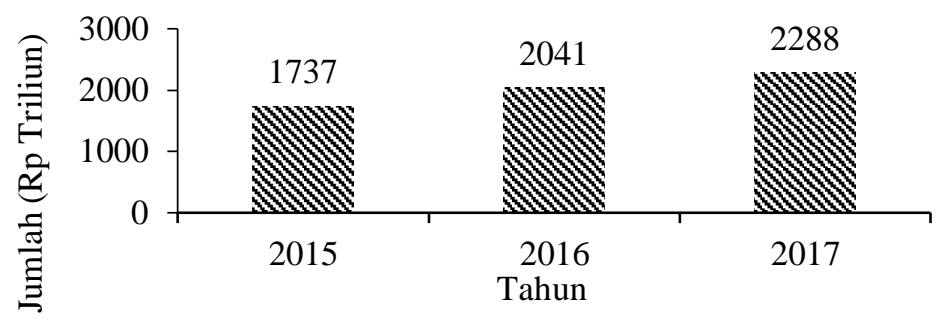

Gambar 3. Kapitalisasi pasar saham JII

Sumber: Otoritas Jasa Keuangan (2018)

Terjadinya peningkatan nilai kapitalisasi saham JII dari tahun 2015 hingga tahun 2017. Nilai kapitalisasi saham JII ini mendominasi lebih dari 60 persen jika dibandingkan dengan nilai kapitalisasi keseluruhan saham syariah di indonesia. Hal ini menunjukkan dominasi saham-saham JII yang kuat. Pemilihan saham yang terdapat pada Jakarta Islamic Index (JII) ini, menggunakan metode perhitungan indeks yang ditetapkan dengan bobot kapitalisasi pasar.

Pengambilan keputusan dalam berinvestasi harus dipertimbangkan saham-saham mana yang akan dipilih terlebih dahulu. Saham yang dipilih adalah saham yang mempunyai prospek progresif yang diukur berdasarkan besarnya tingkat pengembalian yang diharapkan dan tingkat risiko tertentu yang harus ditanggung oleh investor, maka dari itu diperlukan juga analisis yang dalam mengetahui prospek saham JII. Untuk dapat menganalisis kinerja saham-saham yang akan dipilih dibutuhkan adanya portofolio saham. Portofolio saham merupakan kumpulan investasi saham satuan yang diharapkan dapat meminimalkan risiko kerugian. Diversifikasi saham yang terbentuk dari portofolio dapat meminimalisir risiko. Namun, terdapat kelemahan diversifikasi saham yang dilakukan secara acak seperti yang dijelaskan oleh Septyanto dan Kertopati (2014) yaitu, dengan melakukakan penambahan jumlah saham secara terus-menerus dalam suatu portofolio, pada satu titik tertentu dapat mengurangi manfaat dari diversifikasi dan akan meningkatkan risiko. Oleh karena itu, dalam pembentukan portofolio diperlukannya pembentukan portofolio optimal yang memberikan kombinasi terbaik antara tingkat pengembalian yang diharapkan dengan risiko tertentu yang mampu ditoleransi oleh investor. Menurut Bodie et al. dalam Zubir (2011:2) mengatakan bahwa dalam proses investasi saham, harus dianalisis terlebih dahulu tingkat pengembalian dan risikonya, dan kemudian membentuk portofolio optimal dari saham yang dipilih. Portofolio optimal yang dihasilkan dapat dijadikan sebagai dasar dalam pengambilan keputusan berinvestasi.

Pembentukan portofolio optimal dapat dilakukan dengan menggunakan Model Markowitz dan Single Index Model yang nantinya dapat dibandingkan kombinasi mana yang dapat memberikan tingkat pengembalian yang diharapkan dan tingkat risiko terbaik. Model Markowitz hanya mempertimbangkan tingkat pengembalian yang diharapkan dan tingkat risiko serta tidak mempertimbangkan aktiva bebas risiko. Model Markowitz disebut juga dengan mean-variance model. Model Markowitz mempunyai kelebihan yaitu tidak hanya mempertimbangkan sahamsaham agar terdiversifikasi tetapi juga mempertimbangkan titik maksimum diversifikasi saham agar dapat meminimalkan risiko. Menurut Ramadhan et al. (2014), kekurangan dari Model Markowitz adalah penggunaan variance sebagai tingkat ukuran risiko dan penggunaan dari model markowitz tersebut bersifat matematis non linier yang tergolong rumit dibandingkan dengan model lainnya. Sedangkan pemilihan portofolio optimal menggunakan Single Index Model dilakukan dengan membandingkan rasio ERB (excess return to beta) dengan titik $\mathrm{C}^{*}$ (cut off 
point). Rasio ERB merupakan selisih tingkat pengembalian dengan aktiva bebas risiko yang berguna untuk mengukur kelebihan return relatif terhadap satu unit risiko yang tidak dapat didiversifikasikan dan diukur menggunakan beta. Cut-off point merupakan titik pembatas yang menentukan batas nilai ERB. Portofolio optimal dibentuk oleh saham-saham yang memiliki nilai ERB lebih besar atau sama dengan nilai ERB di titik C* (Hartono, 2017).

Penelitian ini melanjutkan penelitian terdahulu Azizah et al. (2016) yang membahas tentang analisis investasi portofolio optimal saham syariah dengan menggunakan Model Markowitz dan Single Index Model pada saham perusahaan yang terdaftar di Jakarta Islamic Index (JII) Periode Desember 2012 - Mei 2015. Perbedaan penelitian ini dengan penelitian terdahulu adalah Pada penelitian terdahulu saham yang diteliti adalah saham JII dengan menggunakan data penutupan harga saham bulanan sedangkan pada penelitian ini menggunakan data harga saham harian. Selanjutnya, pada penelitian terdahulu periode saham syariah JII yang diteliti adalah periode 2012-2015. Sedangkan pada penelitian ini periode yang diteliti adalah periode 2015-2017. Pada penelitian terdahulu, portofolio optimal Model Markowitz hanya menggunakan preferensi risiko minimal sedangkan pada penelitian ini selain menggunakan preferensi risiko minimal juga menggunakan Sharpe Ratio optimal untuk mengukur portofolio optimalnya.

Penelitian ini bertujuan untuk ${ }^{1)}$ menghitung portofolio optimal saham syariah Jakarta Islamic Index dengan menggunakan Model Markowitz dengan preferensi risiko terendah, Model Markowitz dengan sharpe ratio optimal, dan Single Index Model, ${ }^{2}$ membandingkan tingkat pengembalian yang diharapkan dan tingkat risiko portofolio yang terbentuk dari model tersebut, ${ }^{3)}$ untuk memberikan rekomendasi portofolio optimal kepada investor yang dapat dijadikan sebagai bahan pertimbangan pengambilan keputusan dalam berinvestasi pada saham syariah Jakarta Islamic Index.

\section{METODE PENELITIAN}

Pada analisis portofolio optimal saham syariah ini digunakan data harga saham harian JII, data dividen, IHSG, data sukuk pemerintah yang didapatkan dari website Bursa Efek Indonesia http://www.idx.co.id, website yahoo finance http://www.financial.yahoo.com dan perusahaan efek (MNC Sekuritas). Penelitian ini menggunakan metode purposive sampling (nonprobability sampling) dimana dalam penentuan objek penelitan ini didasarkan atas kriteria yang meliputi: semua saham yang masuk indeks Jakarta Islamic Index (JII) dan tidak dikeluarkan selama periode Januari 2015 sampai dengan Desember 2017. Pembentukan portofolio optimal pada penelitian ini menggunakan Model Markowitz dan Single Index Model, dimana Model Markowitz menggunakan dua asumsi yaitu, dengan preferensi risiko terendah dan sharpe ratio optimal. Pengolahan data dilakukan dengan menggunakan Microsoft Excel. Penelitian ini disusun dengan kerangka penelitian yang terdapat pada Gambar 4. 


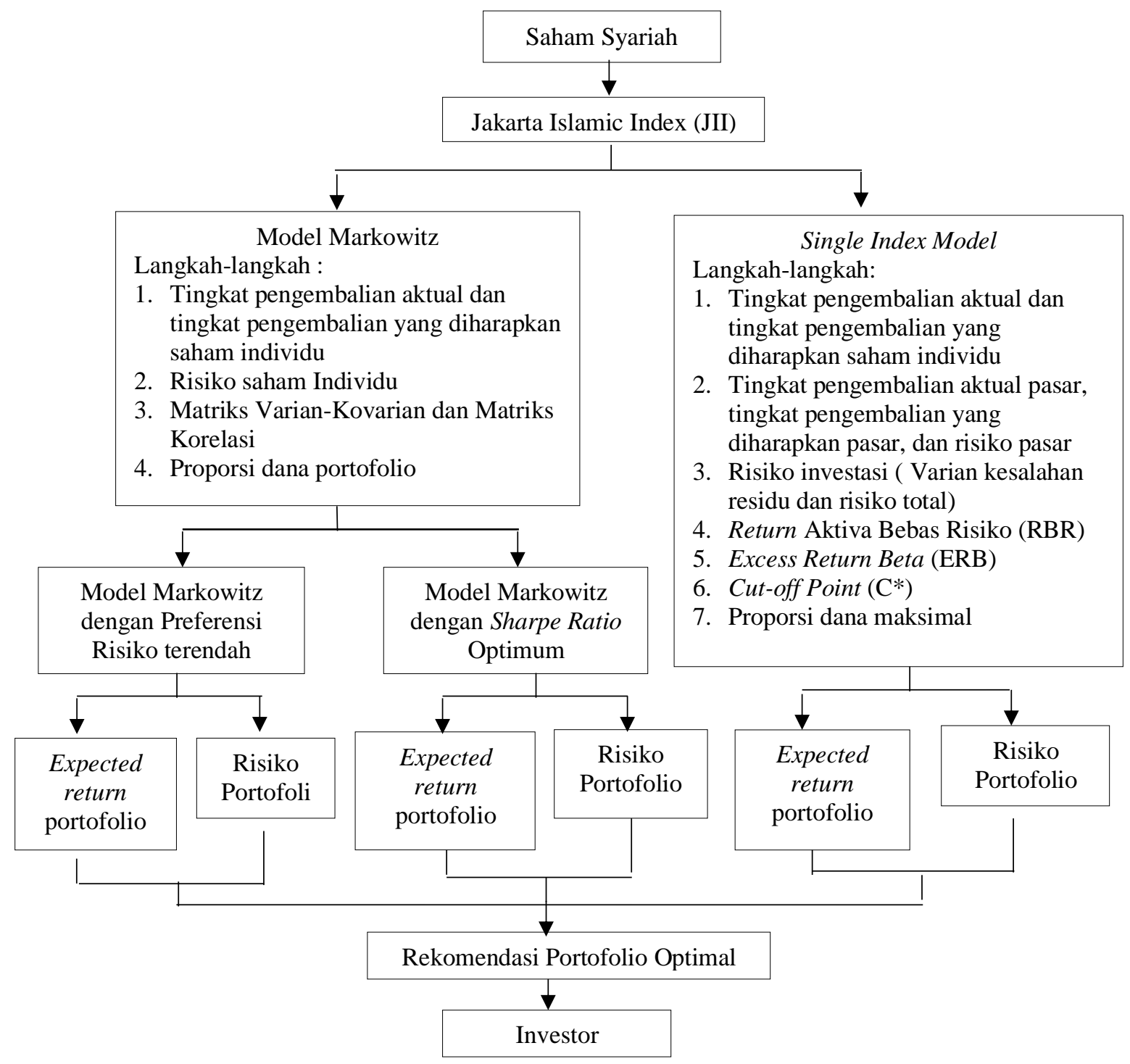

Gambar 4. Kerangka pemikiran penelitian

Penelitian ini diawali dengan mengurutkan seluruh saham yang terdaftar di JII mulai dari Januari 2015 sampai dengan Desember 2017. Kemudian dilakukan penghitungan tingkat pengembalian rata-rata setiap saham individu. Selanjutnya dihitung pembentukan portofolio optimal dengan menggunakan Model Markowitz dan Single Index Model, dimana Model Markowitz menggunakan dua asumsi yaitu, dengan preferensi risiko terendah dan sharpe ratio optimal. Dilakukan perbandingan pembentukan portofolio optimal dengan menggunakan modelmodel tersebut. Kemudian dibandingkan pula tingkat pengembalian yang diharapkan dan risiko portofolio dari kedua model tersebut. Sehingga, diperoleh rekomendasi portofolio optimal dari kedua model tersebut yang dapat memberikan hasil kombinasi tingkat pengembalian yang diharapkan dan tingkat risiko portofolio terbaik. Hasil ini dapat digunakan sebagai dasar dalam pengambilan keputusan investasi di saham syariah JII.

\section{HASIL DAN PEMBAHASAN}

Pembentukan portofolio optimal saham syariah pada penelitian ini menggunakan Model 


\section{Kinerja Saham Individual Berdasarkan Tingkat Pengembalian (Return) dan Risiko}

Investor dalam berinvestasi tentunya menginginkan investasi pada saham-saham yang memiliki kinerja baik. Kinerja sebuah saham dapat dilihat dari kondisi saham tersebut. Pada saham syariah yang terdapat pada Jakarta Islamic Index (JII) periode 2015-2017 dapat diketahui bahwa dari 18 saham terdapat 8 saham yang memiliki kinerja baik dan 10 saham yang memiliki kinerja buruk. Saham dengan kondisi baik merupakan saham yang mampu memberikan tingkat pengembalian aktual positif pada akhir penelitian dan saham yang memiliki kondisi buruk adalah saham yang memberikan tingkat pengembalian aktual negatif di akhir penelitian. Berikut kondisi saham JII yang diperoleh dengan cara melakukan perbandingan harga di saat awal dan akhir penelitian.

Tabel 1. Kondisi saham Jakarta Islamic index

\begin{tabular}{|c|c|c|c|c|c|c|c|c|c|c|c|}
\hline No & $\begin{array}{c}\text { Kode } \\
\text { Saham }\end{array}$ & $\begin{array}{c}\text { Harga } \\
\text { Awal } \\
\text { Periode } \\
\text { (Rupiah) }\end{array}$ & $\begin{array}{c}\text { Harga } \\
\text { akhir } \\
\text { periode } \\
\text { (Rupiah) }\end{array}$ & $(\%)$ & Kondisi & No & $\begin{array}{c}\text { Kode } \\
\text { Saham }\end{array}$ & $\begin{array}{c}\text { Harga } \\
\text { Awal } \\
\text { Periode } \\
\text { (Rupiah) }\end{array}$ & $\begin{array}{c}\text { Harga } \\
\text { akhir } \\
\text { periode } \\
\text { (Rupiah) }\end{array}$ & $(\%)$ & Kondisi \\
\hline 1 & ADRO & 1040 & 1860 & 79 & Baik & 10 & LSIP & 1890 & 1420 & -25 & Buruk \\
\hline 2 & AKRA & 4120 & 6350 & 54 & Baik & 11 & PGAS & 6000 & 1750 & -71 & Buruk \\
\hline 3 & ASII & 7425 & 8300 & 12 & Baik & 12 & PTPP & 3397,95 & 2640 & -22 & Buruk \\
\hline 4 & BSDE & 1805 & 1700 & -6 & Buruk & 13 & SMGR & 16200 & 9900 & -39 & Buruk \\
\hline 5 & ICBP & 6550 & 8900 & 36 & Baik & 14 & SMRA & 1520 & 945 & -38 & Buruk \\
\hline 6 & INCO & 3625 & 2890 & -20 & Buruk & 15 & TLKM & 2865 & 4440 & 55 & Baik \\
\hline 7 & INDF & 6750 & 7625 & 13 & Baik & 16 & UNTR & 17350 & 35400 & 104 & Baik \\
\hline 8 & KLBF & 1830 & 1690 & -8 & Buruk & 17 & UNVR & 32300 & 55900 & 73 & Baik \\
\hline 9 & LPKR & 1020 & 488 & -52 & Buruk & 18 & WIKA & 3407,95 & 1550 & -55 & Buruk \\
\hline
\end{tabular}

Sumber: data diolah (2018)

Selain berdasarkan perbandingan harga awal dan harga akhir saham selama periode penelitian, kinerja saham juga dapat dilihat dari nilai rata-rata tingkat pengembalian. Tingkat pengembalian (return) dan risiko dalam berinvestasi merupakan dua hal yang tidak dapat dipisahkan, karena kedua hal tersebut dijadikan acuan oleh investor dalam pengambilan keputusan investasi. Konsep risiko merupakan salah satu konsep dasar dalam proses pengambilan keputusan investasi yang didasarkan pada tingkat toleransi risiko individu, investor diklasifikasikan menjadi tiga kategori: menghindari risiko, risiko-netral dan pecinta risiko (Pak, 2019). Sedangkan tingkat pengembalian (return) saham terdiri atas tingkat pengembalian aktual (realized return) yang merupakan return yang sudah terjadi, dihitung dengan menggunakan data histori dan tingkat pengembalian yang diharapkan (expected return) yang merupakan return yang diharapkan akan terjadi oleh investor, dihitung dengan menggunakan rata-rata dari realized return selama waktu pengamatan. Tabel 2 berikut menyajikan hasil perhitungan tingkat pengembalian yang diharapkan.

Tabel 2. Hasil perhitungan tingkat pengembalian yang diharapkan sahamindividu (E(Ri))

\begin{tabular}{ccc|ccc|ccc} 
No & $\begin{array}{c}\text { Kode } \\
\text { Saham }\end{array}$ & $\begin{array}{c}\text { E }(\mathrm{Ri}) \\
(\%)\end{array}$ & No & Kode Saham & $\begin{array}{c}\text { E(Ri) } \\
(\%)\end{array}$ & No & Kode Saham & $\begin{array}{c}\text { E(Ri) } \\
(\%)\end{array}$ \\
\hline 1 & ADRO & 0,127 & 7 & INDF & 0,045 & 13 & SMGR & $-0,028$ \\
2 & AKRA & 0,082 & 8 & KLBF & 0,012 & 14 & SMRA & $-0,025$ \\
3 & ASII & 0,045 & 9 & LPKR & $-0,071$ & 15 & TLKM & 0,077 \\
4 & BSDE & 0,016 & 10 & LSIP & 0,046 & 16 & UNTR & 0,137 \\
5 & ICBP & 0,254 & 11 & PGAS & $-0,113$ & 17 & UNVR & 0,090 \\
6 & INCO & 0,022 & 12 & PTPP & $-0,007$ & 18 & WIKA & 2,236 \\
\hline
\end{tabular}

Sumber: data diolah (2018)

Hasil perhitungan tingkat pengembalian yang diharapkan diperoleh dengan cara merataratakan nilai tingkat pengembalian aktual selama periode 2015-2017. Perhitungan ini menghasilkan 13 saham yang memiliki nilai tingkat pengembalian yang diharapkan positif dan lima saham yang memiliki nilai negatif. Tiga belas saham dengan nilai pengembalian yang diharapkan positif ini disajikan oleh Tabel 3. Saham yang memiliki nilai tingkat pengembalian 
yang diharapkan terbesar adalah saham WIKA sebesar 2,23 persen dan nilai terkecil dimiliki oleh saham PGAS sebesar -0,113 persen. Saham yang memperoleh nilai tingkat pengembalian yang diharapkan negatif menunjukkan bahwa saham tersebut tidak memberikan keuntungan kepada investor, sehingga saham-saham tersebut tidak akan dimasukkan kedalam perhitungan portofolio. Selanjutnya akan dihitung risiko saham individual sebagai berikut.

Tabel 3. Nilai Standar Deviasi dan Varian saham individu

\begin{tabular}{cccc|cccc}
\hline No & Kode Saham & $\sigma_{i}$ & $\sigma_{i}^{2}$ & No & Kode Saham & $\sigma_{i}$ & $\sigma_{i}^{2}$ \\
\hline 1 & ADRO & 0,02903 & 0,00084 & 8 & KLBF & 0,01848 & 0,00034 \\
2 & AKRA & 0,02111 & 0,00045 & 9 & LSIP & 0,02667 & 0,00071 \\
3 & ASII & 0,01974 & 0,00039 & 10 & TLKM & 0,01484 & 0,00022 \\
4 & BSDE & 0,02109 & 0,00044 & 11 & UNTR & 0,02449 & 0,00060 \\
5 & ICBP & 0,07088 & 0,00502 & 12 & UNVR & 0,01588 & 0,00025 \\
6 & INCO & 0,03197 & 0,00102 & 13 & WIKA & 0,67378 & 0,45398 \\
\cline { 6 - 8 }
\end{tabular}

Sumber: data diolah (2018)

Hasil perhitungan nilai standar deviasi dan varian saham individu diatas dapat diidentifikasi saham individu yang memiliki risiko terkecil dan terbesar. Saham individual yang memiliki risiko terkecil yaitu saham Telekomunikasi Indonesia (TLKM) dengan nilai standar deviasi sebesar 0,01484 dan nilai varian sebesar 0,00022 . Sedangkan saham yang memiliki risiko terbesar adalah saham Wijaya Karya Tbk (WIKA) dengan nilai standar deviasi sebesar 0,67378 dan nilai varian sebesar 0,45398. Sedangkan untuk mengetahui hubungan antar saham, penelitian ini menggunakan Matriks Kovarian dan Matriks Korelasi yang diolah dengan menggunakan fasilitas Analysis Toolpak yang tersedia pada Microsoft Excel.

\section{Portofolio Model Markowitz}

Strategi yang dapat dilakukan oleh investor dalam berinvestasi adalah dengan melakukan optimasi portofolio (Ivanova \& Dostpaliev, 2017). Optimasi portofolio salah satunya dapat dilakukan dengan menggunakan Model Markowitz, dimana model ini mengukur kinerja saham berdasarkan tingkat pengembalian dan risikonya. Pada proses pembentukan portofolio diperlukan keputusan alokasi aktiva yaitu, keputusan untuk menentukan aktiva yang akan digunakan atau dialokasikan ke dalam portofolio. Kumpulan dari banyak kombinasi aktiva tersebut membentuk banyak portofolio efisien dan hanya portofolio dengan kinerja terbaik yang bisa disebut dengan portofolio optimum. Portofolio optimal merupakan portofolio yang memberikan hasil kombinasi tingkat pengembalian yang diharapkan dan risiko terbaik (Hartono, 2017). Kombinasi saham dan proporsi dana investasi yang membentuk portofolio Model Markowitz berdasarkan risiko terkecil terdapat pada Tabel 4.

Tabel 4. Kombinasi dan alokasi dana portofolio Model Markowitz berdasarkan Preferensi Risiko Terkecil dengan Solver

\begin{tabular}{cllcr}
\hline No & $\begin{array}{c}\text { Kode } \\
\text { Saham }\end{array}$ & \multicolumn{1}{c}{ Nama Perusahaan } & $\begin{array}{c}\text { Expected Return } \\
(\mathrm{E}(\mathrm{Ri}))(\%)\end{array}$ & $\begin{array}{c}\text { Proporsi/ Alokasi } \\
\text { Dana }(\%)\end{array}$ \\
\hline 1 & ADRO & Adaro Energy Tbk. & 0,127 & 2,27 \\
2 & AKRA & AKR Corporindo Tbk. & 0,082 & 15,44 \\
3 & ASII & Astra International Tbk. & 0,045 & 6,26 \\
4 & BSDE & Bumi Serpong Damai Tbk. & 0,016 & - \\
5 & ICBP & Indofood CBP Sukses Makmur Tbk. & 0,254 & 0,64 \\
6 & INCO & Vale Indonesia Tbk & 0,022 & 0,01 \\
7 & INDF & Indofood Sukses Makmur Tbk. & 0,045 & 3,33 \\
8 & KLBF & Kalbe Farma Tbk. & 0,012 & 14,44 \\
9 & LSIP & PP London Sumatra Indonesia Tbk. & 0,046 & 9,88 \\
10 & TLKM & Telekomunikasi Indonesia (Persero) Tbk. & 0,077 & 25,46 \\
11 & UNTR & United Tractors Tbk. & 0,137 & 2,66 \\
12 & UNVR & Unilever Indonesia Tbk. & 0,090 & 19,51 \\
13 & WIKA & Wijaya Karya (Persero) Tbk. & 2,236 & 0,12 \\
\hline
\end{tabular}

Sumber: data diolah (2018) 
Model Markowitz dengan preferensi risiko terkecil menghasilkan sebanyak 12 kombinasi saham dengan alokasi dana terbesar terdapat pada saham TLKM sebesar 25,46 persen dan alokasi dana terkecil terdapat pada saham INCO sebesar 0,01 persen. Kombinasi saham dan proporsi alokasi dana ini menghasilkan tingkat pengembalian yang diharapkan dan risiko sebagai berikut.

Tabel 5. Pembentukan tingkat pengembalian, risiko, dan kinerja portofolio Model Markowitz dengan preferensi risiko terkecil

\begin{tabular}{llr} 
& Harian & Tahunan \\
\hline Tingkat pengembalian portofolio yang diharapkan $(\%)$ & 0,0711 & 18,50 \\
Risiko portofolio minimum $(\%)$ & 1,0755 & 17,34 \\
Tingkat pengembalian bebas risiko $(\%)$ & 0,0154 & 5,62 \\
Sharpe ratio (Kinerja portofolio) & 0,051826 & \\
\hline
\end{tabular}

Sumber: data diolah, 2018

Apabila investor menginvestasikan dananya pada saham-saham yang terdapat pada Tabel 5, maka diharapkan dapat memberikan tingkat pengembalian keseluruhan investasi sebesar 18,50 persen dan kinerja portofolio yang diukur dengan menggunakan Sharpe Ratio sebesar 0,051826. Misalkan jika investor memiliki dana sebesar Rp 1 Miliar maka dengan berdasarkan informasi dari Tabel 5 maka akan diperoleh tingkat pengembalian portolio yang diharapkan atau keuntungan sebesar Rp 185.000.000,-. Kombinasi tersebut merupakan kombinasi portofolio efisien berdasarkan preferensi investor yang risk averse atau cenderung menghindari risiko.

Pembentukan portofolio Model Markowitz selanjutnya adalah dengan mengoptimalkan kinerja portofolio yang diukur menggunakan Sharpe Ratio, yang diolah dengan menggunakan fasilitas Solver yang terdapat pada Microsoft Excel. Berikut kombinasi saham dan proporsinya yang membentuk portofolio Model Markowitz dengan menggunakan Sharpe Ratio optimal.

Tabel 6. Kombinasi dan alokasi dana portofolio Model Markowitz berdasarkan Sharpe Ratio optimal

\begin{tabular}{lllrc}
\hline No & $\begin{array}{c}\text { Kode } \\
\text { Saham }\end{array}$ & \multicolumn{1}{c}{ Nama Perusahaan } & $\begin{array}{c}\text { Expected } \\
\text { Return (E(Ri)) } \\
(\%)\end{array}$ & $\begin{array}{c}\text { Proporsi/ } \\
\text { Alokasi Dana } \\
(\%)\end{array}$ \\
\hline 1 & ADRO & Adaro Energy Tbk. & 0,127 & 11,21 \\
2 & AKRA & AKR Corporindo Tbk. & 0,082 & 13,47 \\
3 & ASII & Astra International Tbk. & 0,045 & - \\
4 & BSDE & Bumi Serpong Damai Tbk. & 0,016 & - \\
5 & ICBP & Indofood CBP Sukses Makmur Tbk. & 0,254 & 6,03 \\
6 & INCO & Vale Indonesia Tbk & 0,022 & - \\
7 & INDF & Indofood Sukses Makmur Tbk. & 0,045 & - \\
8 & KLBF & Kalbe Farma Tbk. & 0,012 & - \\
9 & LSIP & PP London Sumatra Indonesia Tbk. & 0,046 & 18,90 \\
10 & TLKM & Telekomunikasi Indonesia (Persero) Tbk. & 0,077 & 19,89 \\
11 & UNTR & United Tractors Tbk. & 0,137 & 29,57 \\
12 & UNVR & Unilever Indonesia Tbk. & 0,090 & 0,93 \\
13 & WIKA & Wijaya Karya (Persero) Tbk. & 2,236 & \\
\hline
\end{tabular}

Sumber: data diolah (2018)

Pembentukan portofolio Model Markowitz dengan mengoptimalkan kinerja portofolio yang diukur menggunakan Sharpe Ratio menghasilkan sebanyak tujuh kombinasi saham, yaitu ADRO, AKRA, ICBP, TLKM, UNTR, UNVR, dan WIKA (Tabel 6). Alokasi dana terbesar terdapat pada saham UNVR sebesar 29,57 persen dan alokasi dana terkecil terdapat pada saham WIKA sebesar 0,93 persen. Kombinasi saham dan proporsi alokasi dana ini menghasilkan tingkat pengembalian yang diharapkan dan risiko sebagai berikut. 
Tabel 7. Pembentukan tingkat pengembalian, risiko, dan kinerja portofolio Model Markowitz dengan Sharpe ratio optimal

\begin{tabular}{lcc}
\hline & Harian & Tahunan \\
\hline Tingkat pengembalian portofolio yang diharapkan (\%) & 0,1298 & 33,74 \\
Risiko portofolio (\%) & 1,3852 & 22,34 \\
Tingkat pengembalian bebas risiko (\%) & 0,0154 & 5,62 \\
Sharpe ratio optimal (Kinerja portofolio) & 0,082573 & \\
\hline
\end{tabular}

Sumber: data diolah (2018)

Apabila investor menginvestasikan dananya pada 7 kombinasi saham dengan perhitungan dengan menggunakan Model Markowitz berdasarkan Sharpe ratio optimal yang terdapat pada Tabel 7 maka dihasilkan kinerja portofolio sebesar 0,082573 dan dapat memberikan tingkat pengembalian keseluruhan investasi yang diharapkan sebesar 33,74 persen. Hal ini akan lebih tergambar jika misalnya investor memiliki dana sebesar Rp 1 Miliar dan menginvestasikan sesuai dengan besar alokasi dana yang telah didapatkan dari Tabel 7, maka investor akan memperoleh tingkat pengembalian portolio yang diharapkan atau keuntungan sebesar Rp 337.400.000,-Portofolio dengan kombinasi tersebut merupakan portofolio yang dapat digunakan bagi investor risk taker, tetapi masih juga mempertimbangkan risiko dan kinerja dari portofolionya.

\section{Portofolio Single Index Model}

Pembentukan portofolio optimal dengan menggunakan Single Index Model didasarkan pada pergerakan indeks pasar bahwa harga dari suatu emiten saham bergerak searah dengan indeks harga pasarnya. Apabila indeks harga dari saham gabungan naik, maka harga $\mathrm{n}$-aset saham kesuluruhan juga mengalami kecenderungan naik. Pergerakan yang searah mengindikasikan bahwa imbal hasil $\mathrm{n}$-aset saham cenderung berkorelasi positif dengan return pasar.

\section{Perhitungan Return Bebas Risiko (RBR)}

Pada perhitungan Single Index Model ini digunakan data sukuk pemerintah sebagai return bebas risikonya dengan nilai sukuk sebesar 5,62 persen pertahun dan 0,00154 per hari. Data sukuk yang digunakan adalah data per hari yaitu sebesar 0,000154 untuk dapat menyeleksi saham. Berikut ini disajikan seleksi saham berdasarkan return bebas risiko pada Tabel 8 .

Tabel 8. Saham calon portofolio

\begin{tabular}{lllccc}
\hline No & $\begin{array}{l}\text { Kode } \\
\text { Saham }\end{array}$ & \multicolumn{1}{c}{ Nama Perusahaan } & $\begin{array}{c}\text { Tingkat } \\
\text { Pengembalian } \\
\text { yang Diharapkan } \\
(\mathrm{E}(\mathrm{Ri})(\%)\end{array}$ & $\begin{array}{c}\text { RBR } \\
(\%)\end{array}$ & Keterangan \\
\hline 1 & ADRO & Adaro Energy Tbk. & 0,127 & 0,0154 & $\mathrm{E}(\mathrm{Ri})>\mathrm{RBR}$ \\
2 & AKRA & AKR Corporindo Tbk. & 0,082 & 0,0154 & $\mathrm{E}(\mathrm{Ri})>\mathrm{RBR}$ \\
3 & ASII & Astra International Tbk. & 0,045 & 0,0154 & $\mathrm{E}(\mathrm{Ri})>\mathrm{RBR}$ \\
4 & BSDE & Bumi Serpong Damai Tbk. & 0,016 & 0,0154 & $\mathrm{E}(\mathrm{Ri})>\mathrm{RBR}$ \\
5 & ICBP & Indofood CBP Sukses Makmur Tbk. & 0,254 & 0,0154 & $\mathrm{E}(\mathrm{Ri})>\mathrm{RBR}$ \\
6 & INCO & Vale Indonesia Tbk & 0,022 & 0,0154 & $\mathrm{E}(\mathrm{Ri})>\mathrm{RBR}$ \\
7 & INDF & Indofood Sukses Makmur Tbk. & 0,045 & 0,0154 & $\mathrm{E}(\mathrm{Ri})>\mathrm{RBR}$ \\
8 & KLBF & Kalbe Farma Tbk. & 0,012 & 0,0154 & $\mathrm{E}(\mathrm{Ri})<\mathrm{RBR}$ \\
9 & LSIP & PP London Sumatra Indonesia Tbk. & 0,046 & 0,0154 & $\mathrm{E}(\mathrm{Ri})>\mathrm{RBR}$ \\
10 & TLKM & Telekomunikasi Indonesia (Persero) Tbk. & 0,077 & 0,0154 & $\mathrm{E}(\mathrm{Ri})>\mathrm{RBR}$ \\
11 & UNTR & United Tractors Tbk. & 0,137 & 0,0154 & $\mathrm{E}(\mathrm{Ri})>\mathrm{RBR}$ \\
12 & UNVR & Unilever Indonesia Tbk. & 0,090 & 0,0154 & $\mathrm{E}(\mathrm{Ri})>\mathrm{RBR}$ \\
13 & WIKA & Wijaya Karya (Persero) Tbk. & 2,236 & 0,0154 & $\mathrm{E}(\mathrm{Ri})>\mathrm{RBR}$ \\
\hline
\end{tabular}

Sumber: data diolah (2018)

Terdapat 12 saham yang memenuhi kriteria yang mempunyai nilai tingkat pengembalian yang diharapkan lebih besar dari return bebas risiko $(\mathrm{E}(\mathrm{Ri})>\mathrm{RBR})$ dan satu saham yang memiliki nilai tingkat pengembalian yang diharapkan lebih kecil dibandingkan return bebas risiko yaitu 
saham KLBF. Alasan yang mendasari penyeleksian saham berdasarkan return bebas risiko ini adalah agar investor dapat membandingkan tingkat pengembalian saham individual yang memiliki risiko dengan investasi pada aktiva yang tidak berisiko dimana disini digunakan sukuk pemerintah sebagai aktiva bebas risikonya. Saham-saham yang memenuhi kriteria E(Ri)>RBR akan dimasukkan dalam perhitungan pembentukan portofolio selanjutnya.

Beta $(\beta)$ dan Alpha $(\alpha)$

Beta $(\beta)$ adalah pengukur risiko sistematis dari suatu saham atau portofolio relatif terhadap risiko pasar dan berfungsi sebagai pengukur volatilitas return saham, atau portofolio terhadap return pasar. Pada penelitian ini untuk perhitungan Beta digunakan program excel dengan rumus slope, yaitu menghitung keserongan return realisasi saham dengan perhitungan return pasar pada periode tertentu. Sedangkan Alpha ( $\alpha$ i) merupakan nilai ekspektasian dari return aktiva yang independen terhadap return pasar. Nilai Beta $(\beta i)$ dan Alpha ( $\alpha$ i) saham JII terdapat pada Tabel 9 sebagai berikut.

Tabel 9. Nilai Beta ( $\beta i$ ) dan Alpha ( $\alpha i)$ Saham Individual

\begin{tabular}{cccc|cccc}
\hline No & \multirow{2}{*}{ Kode Saham } & Bi & $\alpha i$ & No & $\begin{array}{c}\text { Kode } \\
\text { Saham }\end{array}$ & $\beta i$ & $\alpha i$ \\
\hline 1 & ADRO & 144,004 & 0,00086 & 7 & INDF & 143,257 & 0,00004 \\
2 & AKRA & 0,66339 & 0,00063 & 8 & LSIP & 0,86306 & 0,00022 \\
3 & ASII & 155,067 & 0,00001 & 9 & TLKM & 103,749 & 0,00048 \\
4 & BSDE & 161,247 & $-0,00030$ & 10 & UNTR & 137,781 & 0,00097 \\
5 & ICBP & 0,96524 & 0,00226 & 11 & UNVR & 111,382 & 0,00058 \\
6 & INCO & 135,797 & $-0,00017$ & 12 & WIKA & $-339,083$ & 0,02333 \\
\hline
\end{tabular}

Sumber: data diolah (2018)

\section{Excess Return Beta}

Selisih antara tingkat pengembalian yang diharapkan dengan return aktiva bebas risiko disebut dengan excess return beta. Portofolio yang optimal akan berisi aktiva-aktiva yang memiliki nilai rasio ERB yang tinggi. Aktiva yang memiliki nilai rasio rendah tidak akan dimasukkan kedalam porofolio. Oleh karena itu dibutuhkan titik pembatas (cut-off point) untuk menentukan batas nilai ERB. Berikut ini hasil perhitungan ERB dari yang terbesar ke yang terkecil.

Tabel 10. Nilai ERB saham individu

\begin{tabular}{ccc|ccc}
\hline No & Kode Saham & ERBi $(\%)$ & No & Kode Saham & ERBi $(\%)$ \\
\hline 1 & ICBP & 0,00247 & 7 & LSIP & 0,00036 \\
2 & AKRA & 0,00101 & 8 & INDF & 0,00021 \\
3 & UNTR & 0,00088 & 9 & ASII & 0,00019 \\
4 & ADRO & 0,00078 & 10 & INCO & 0,00005 \\
5 & UNVR & 0,00067 & 11 & BSDE & 0,00001 \\
6 & TLKM & 0,00060 & 12 & WIKA & $-0,00655$ \\
\hline
\end{tabular}

Sumber: data diolah (2018)

Saham yang memiliki nilai ERB tertinggi adalah saham Indofood CBP Sukses Makmur Tbk (ICBP) sebesar 0,247 persen. Sedangkan saham yang memiliki nilai ERB paling kecil adalah saham Wijaya Karya Tbk (WIKA) sebesar -0,655 persen. Nilai ERB ini selanjutnya akan diseleksi dengan menggunakan nilai cut-off point.

Menghitung Cut-off Point

Cut-off point $\left(\mathrm{C}^{*}\right)$ digunakan untuk membatasi nilai ERB yang akan dimasukkan kedalam portofolio. Untuk menyederhanakan rumus $\mathrm{C}^{*}$ yang rumit, maka rumus ini dipecah menjadi komponen Ai dan Bi yang terdapat pada Tabel 11. 
Tabel 11. Nilai Ai dan Bi saham individual

\begin{tabular}{|c|c|c|c|c|c|c|c|}
\hline No & Kode Saham & $\mathrm{Ai}$ & $\mathrm{Bi}$ & No & $\begin{array}{l}\text { Kode } \\
\text { Saham }\end{array}$ & $\mathrm{Ai}$ & $\mathrm{Bi}$ \\
\hline 1 & ICBP & 0,48024 & 187,90 & 7 & LSIP & 0,46632 & 1130,25 \\
\hline 2 & AKRA & 161,026 & 1060,98 & 8 & INDF & 125,803 & 8775,70 \\
\hline 3 & UNTR & 259,969 & 4069,64 & 9 & ASII & 132,733 & 10883,16 \\
\hline 4 & ADRO & 160,655 & 2974,46 & 10 & INCO & 0,06872 & 2065,90 \\
\hline 5 & UNVR & 450,786 & 7509,35 & 11 & BSDE & 0,03391 & 9906,96 \\
\hline 6 & TLKM & 427,962 & 7441,50 & 12 & WIKA & 0,04900 & 25,37 \\
\hline
\end{tabular}

Sumber: data diolah (2018)

Setelah diperoleh hasil perhitungan $\mathrm{Ai}$ dan Bi maka dapat dihitung besarnya nilai $\mathrm{Ci}$ yang terdapat pada Tabel 12. Nilai Ci terbesar merupakan nilai cut-off point $\left(\mathrm{C}^{*}\right)$.

Tabel 12 Nilai Ci saham individual

\begin{tabular}{cccclc}
\hline No & $\begin{array}{c}\text { Kode } \\
\text { Saham }\end{array}$ & Ci $(\%)$ & No & $\begin{array}{c}\text { Kode } \\
\text { Saham }\end{array}$ & Ci $(\%)$ \\
\hline 1 & ICBP & 0,003 & 7 & LSIP & 0,040 \\
2 & AKRA & 0,013 & 8 & INDF & 0,035 \\
3 & UNTR & 0,024 & 9 & ASII & 0,031 \\
4 & ADRO & 0,028 & 10 & INCO & 0,030 \\
5 & UNVR & 0,036 & 11 & BSDE & 0,026 \\
6 & TLKM & 0,040 & 12 & WIKA & 0,026 \\
\hline
\end{tabular}

Sumber: data diolah (2018)

Nilai Ci terbesar terdapat pada perusahaan Telekomunikasi Indonesia Tbk (TLKM) dan PP London Sumatra Indonesia Tbk (LSIP) sebesar 0,040 persen. Nilai Ci terbesar merupakan nilai cut-off point (titik pembatas) untuk menentukan batas nilai ERB. Sehingga saham yang memenuhi kriteria nilai ERB lebih besar dari nilai $C^{*}$ bisa dimasukkan kedalam pemilihan saham portofolio optimal.

Tabel 13. Pemilihan saham portofolio

\begin{tabular}{cllccc}
\hline No & $\begin{array}{l}\text { Kode } \\
\text { Saham }\end{array}$ & \multicolumn{1}{c}{ Nama Perusahaan } & Ci* $(\%)$ & ERB (\%) & Keterangan \\
\hline 1 & ICBP & Indofood CBP Sukses Makmur Tbk. & 0,040 & 0,247 & Terpilih \\
2 & AKRA & AKR Corporindo Tbk. & 0,040 & 0,101 & Terpilih \\
3 & UNTR & United Tractors Tbk. & 0,040 & 0,088 & Terpilih \\
4 & ADRO & Adaro Energy Tbk. & 0,040 & 0,078 & Terpilih \\
5 & UNVR & Unilever Indonesia Tbk. & 0,040 & 0,067 & Terpilih \\
6 & TLKM & Telekomunikasi Indonesia (Persero) Tbk. & 0,040 & 0,060 & Terpilih \\
7 & LSIP & PP London Sumatra Indonesia Tbk. & 0,040 & 0,036 & Tidak \\
8 & INDF & Indofood Sukses Makmur Tbk. & 0,040 & 0,021 & Tidak \\
9 & ASII & Astra International Tbk. & 0,040 & 0,019 & Tidak \\
10 & INCO & Vale Indonesia Tbk. & 0,040 & 0,005 & Tidak \\
11 & BSDE & Bumi Serpong Damai Tbk. & 0,040 & 0,001 & Tidak \\
12 & WIKA & Wijaya Karya (Persero) Tbk. & 0,040 & $-0,655$ & Tidak \\
\hline
\end{tabular}

Sumber: data diolah (2018)

Tampak pada Tabel 13 terdapat enam kombinasi saham yang terpilih dari portofolio Single Index Model dan enam saham juga yang tidak masuk dalam portofolio tersebut. Saham yang terpilih masuk portofolio optimal yaitu saham Indofood CBP Sukses Makmur Tbk (ICBP), AKR Corporindo Tbk (AKRA), United Tractors Tbk (UNTR), Adaro Energy Tbk (ADRO), dan Unilever Indonesia Tbk (UNVR), Telekomunikasi Indonesia Tbk (TLKM) . 
$\underline{\text { Komposisi Dana }}$

Perhitungan komposisi dana ini bertujuan untuk mengetahui seberapa besar proporsi alokasi dana yang akan diinvestasikan untuk masing-masing saham yang telah membentuk portofolio Single Index Model. Berikut ini disajikan komposisi alokasi dana yang membentuk portofolio Single Index Model pada Tabel 14.

Tabel 14. Nilai Zi dan wi (proporsi alokasi dana) saham terpilih

\begin{tabular}{|c|c|c|c|c|}
\hline No & $\begin{array}{l}\text { Kode } \\
\text { Saham }\end{array}$ & Nama Perusahaan & $\mathrm{Zi}$ & $\begin{array}{c}\text { Proporsi/ Alokasi } \\
\text { Dana }(\%)\end{array}$ \\
\hline 1 & ICBP & Indofood CBP Sukses Makmur Tbk. & 0,40189 & 5,96 \\
\hline 2 & AKRA & AKR Corporindo Tbk. & 0,96655 & 14,34 \\
\hline 3 & UNTR & United Tractors Tbk. & 141,087 & 20,93 \\
\hline 4 & ADRO & Adaro Energy Tbk. & 0,77521 & 11,50 \\
\hline 5 & UNVR & Unilever Indonesia Tbk. & 179,434 & 26,62 \\
\hline 6 & TLKM & Telekomunikasi Indonesia (Persero) Tbk. & 139,277 & 20,66 \\
\hline
\end{tabular}

Sumber: data diolah (2018)

Terdapat enam kombinasi saham yang diperoleh dengan menggunakan perhitungan Single Index Model. Komposisi dana terbesar dimiliki oleh saham Unilever Indonesia Tbk (UNVR) sebesar 26,62 persen dan yang terkecil dimiliki oleh saham Indofood CBP Sukses Makmur Tbk (ICBP) sebesar 5,96 persen.

Tabel 15. Tingkat pengembalian yang diharapkan, risiko dan kinerja portofolio Single Index Model

\begin{tabular}{lcc}
\hline & Harian & Tahunan \\
\hline Tingkat pengembalian portofolio yang diharapkan $(\%)$ & 0,110 & 28,61 \\
Risiko portofolio $(\%)$ & 1,270 & 20,47 \\
Tingkat pengembalian bebas risiko $(\%)$ & 0,0154 & 5,62 \\
Alpha Portofolio $(\alpha p)$ & 0,000782 & - \\
Beta Portofolio $(\beta p)$ & 1,117374 & - \\
Sharpe ratio (Kinerja portofolio) & 0,07454 & - \\
\hline
\end{tabular}

Sumber: data diolah (2018)

Apabila investor ingin menginvestasikan dananya pada hasil perhitungan portofolio Single Index Model, maka akan diperoleh tingkat pengembalian yang diharapkan atau keuntungan dari keseluruhan saham tersebut adalah sebesar 28,61 persen pertahun. Jika dimisalkan investor ingin menginvestasikan dananya sebesar Rp 1 Miliar maka akan diperoleh tingkat pengembalian yang diharapkan atau keuntungan sebesar Rp 286,1 Juta dengan Beta Portofolio ( $\beta$ p) sebesar 1,12 yang artinya investor akan memperoleh tingkat pengembalian atau keuntungan lebih besar dibandingkan dengan tingkat pengembalian pasar.

\section{Komparasi Hasil Perhitungan Model Markowitz dan Single Index Model}

Komparasi hasil perhitungan portofolio dengan menggunakan Model Markowitz dan Single Index Model disajikan pada Tabel 16 sebagai berikut.

Tabel 16. Komparasi hasil perhitungan Model Markowitz dan Single Index Model

\begin{tabular}{lccc} 
& \multicolumn{2}{c}{ Model Markowitz } & \\
& Preferensi & Sharpe Ratio & Single Index Model \\
& Risiko & Optimal & \\
\hline Terendah & 12 Saham & 7 Saham & 6 Saham \\
& 17,34 & 22,34 & 20,47 \\
Risiko Portofolio (\%) & 18,50 & 33,74 & 28,61 \\
Tingkat Pengembalian Portofolio (\%) & 0,051826 & 0,082573 & 0,074540 \\
Sharpe Ratio & & &
\end{tabular}

Sumber: data diolah (2018)

Komparasi hasil perhitungan portofolio dengan menggunakan Model Markowitz dan Single Index Model diatas diperoleh hasil kombinasi tingkat pengembalian yang diharapkan dan risiko portofolio terbaik pada perhitungan portofolio dengan menggunakan Model Markowitz Sharpe Ratio Optimal. Dapat dilihat juga pada scatterplot perbandingan tingkat pengembalian 
yang diharapkan dan risiko dari masing-masing portofolio per tahunnya selama periode penelitian yang terdapat pada Gambar 5.

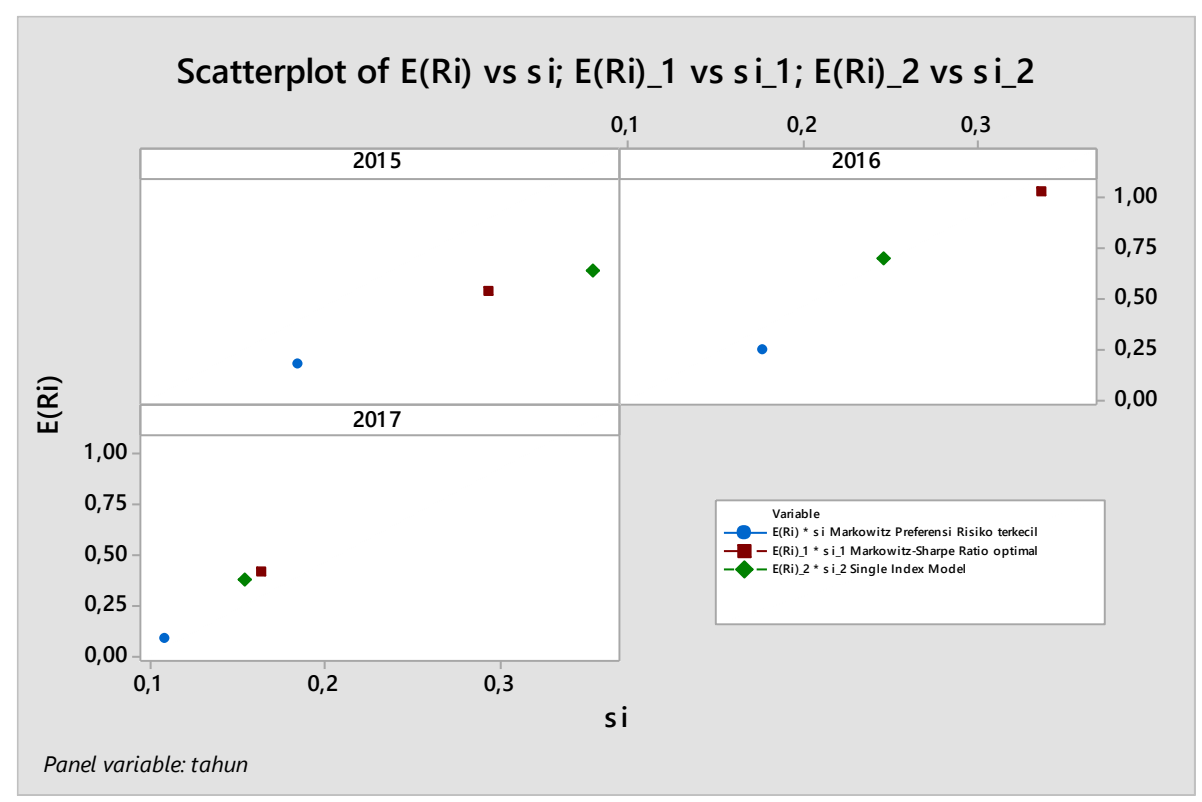

Gambar 5. Perbandingan tingkat pengembalian yang diharapkan dan risiko dari masing-masing portofolio per tahun

Berdasarkan Gambar 5 dapat dilihat perbandingan dari ketiga model pembentukan portofolio optimal di tahun 2015, 2016 dan 2017. Hasil perbandingan kombinasi tingkat pengembalian yang diharapkan $\left(E\left(R_{i}\right)\right.$ dan risiko portofolio per tahun menunjukkan bahwa pada tahun 2015 penggunaan model portofolio terbaik adalah menggunakan Single Index Model sedangkan pada tahun 2016 dan 2017 penggunaan model portofolio yang optimal atau terbaik adalah menggunakan Model Markowitz dengan Sharpe ratio optimal. Berdasarkan perbandingan selama tiga tahun tersebut dapat ditentukan bahwa model yang dapat memberikan kombinasi tingkat pengembalian portofolio yang diharapkan dan risiko terbaik adalah menggunakan perhitungan portofolio Model Markowitz dengan kinerja optimal yang diukur dengan menggunakan Sharpe ratio. Saham-saham yang masuk kedalam portofolio optimal ini sudah terdiversikasi dengan baik dimana diversifikasi saham termasuk ke dalam salah satu bentuk mitigasi risiko (Respati, 2017).

\section{Implikasi Manajerial}

Strategi investasi yang tepat diperlukan untuk menghindari potensi kerugian yang mungkin terjadi terhadap investor dalam menginvestasikan modalnya dengan mengantisipasi perubahan kondisi pasar, pergerakan saham, kondisi ekonomi, dan bisa juga dilihat dari profit perusahaan yang dapat mempengaruhi tingkat pengembalian yang diharapkan dan tingkat risiko. Salah satu strategi yang tepat untuk menghindari kerugian yang mungkin terjadi terhadap investor adalah dengan mengivestasikan dana pada saham-saham yang memiliki kinerja terbaik yang dapat diperoleh melalui perhitungan portofolio optimal. Kombinasi saham yang memiliki kinerja terbaik tersebut diperoleh menggunakan Model Markowitz dengan Sharpe ratio optimal yaitu investasi pada saham ADRO, AKRA, ICBP, TLKM, UNTR, UNVR, dan WIKA dengan besaran proporsi alokasi dana yang telah ditentukan pada penelitian ini. Hasil pembentukan portofolio optimal yang memberikan hasil kombinasi tingkat pengembalian yang diharapkan dan tingkat risiko portofolio terbaik dari hasil perhitungan beberapa metode dalam penelitian ini dapat digunakan sebagai dasar dalam pengambilan keputusan investasi oleh investor untuk berinvestasi di saham syariah JII. 


\section{KESIMPULAN}

Berdasarkan hasil penelitian dan pembahasan yang telah dikemukakan dapat disimpulkan bahwa, diperoleh 12 kombinasi saham pada perhitungan portofolio menggunakan Model Markowitz dengan preferensi risiko terendah dan 7 kombinasi saham berdasarkan perhitungan Model Markowitz dengan Sharpe ratio optimal serta sebanyak 6 kombinasi saham pada perhitungan portofolio Single index Model. Pada portofolio model Markowitz dengan preferensi risiko terendah diperoleh tingkat pengembalian portofolio yang diharapkan dalam satu tahun sebesar 18,50 persen, risiko portofolio sebesar 17,34 persen, dan kinerja portofolio sebesar 0,051826. Perhitungan portofolio optimal Model Markowitz dengan Sharpe ratio optimal menghasilkan tingkat pengembalian portofolio yang diharapkan portofolionya dalam satu tahun sebesar 33,74 persen, risiko portofolionya sebesar 22,34 persen, dan kinerja portofolio sebesar 0,082573. Sedangkan perhitungan portofolio menggunakan Single Index Model diperoleh tingkat pengembalian portofolio yang diharapkan dalam satu tahun sebesar 28,61 persen, risiko portofolio sebesar 20,47 persen, dan kinerja portofolio sebesar 0,07454. Berdasarkan beberapa hasil perhitungan tersebut, diperoleh model yang menghasilkan portofolio optimal adalah Model Markowitz dengan Sharpe ratio optimal yang menghasilkan kombinasi tingkat pengembalian portofolio yang diharapkan dan risiko portofolio terbaik dibandingkan dengan Single Index Model. Investor dapat menggunakan hasil penelitian ini sebagai bahan pertimbangan dalam menginvestasikan dananya pada saham syariah Jakarta Islamic Index (JII).

\section{DAFTAR PUSTAKA}

Azizah, D. F., Topowijono, \& Sulasmiyati, S. (2016). Analisis Investasi Portofolio Optimal Saham Syariah dengan Menggunakan Model Markowitz dan Single Index Model. (Studi pada Saham Perusahaan yang Terdaftar di Jakarta Islamic Index (JII) Periode Desember 2012 - Mei 2015). Jurnal Administrasi Bisnis, 42(1), 1-19.

Hidayat, T. (2011). Buku Pintar Investasi Syariah. Jakarta: Mediakita.

Hartono, J. (2017). Teori Portofolio dan Analisis Investasi Ed Ke-11. Yogyakarta: BPFE.

Ivanova, M., \& Dospatliev, L. (2017). Aplication of Markowitz Portfolio Optimization on Bulgarian Stock Market from 2013 to 2016. International Journal of Pure and Applied Mathematics, 117(2), 291-307.

[OJK] Otoritas Jasa Keuangan. (2017). Statistik Saham Syariah dari tahun 2012-2017 [Internet]. [diunduh 2018 Januari 20]. Tersedia pada: http://www.ojk.go.id/id/kanal/syariah/data-danstatistik/saham-syariah/Documents/Pages/Statistik-Saham-Syariah---Desember2017/Statistik\%20Saham-2017\%20DES.pdf.

Ramadhan, R. D., Handayani, M. G., \& Endang, M. G. W. (2014). Analisis Pemilihan Portofolio Optimal Dengan Model Dan Pengembangan Dari Portofolio Markowitz (Studi pada indeks BISNIS-27 di Bursa Efek Indonesia periode 2011-2013). Jurnal Administrasi Bisnis, 14(1), $1-10$.

Respati, P. (2017). Anomali "Beta Negatif" dan Kontribusinya terhadap Pembentukan Portofolio Optimal dalam Kondisi Pasar Bullish dan Bearish. Bogor: Institut Pertanian Bogor.

Septyanto, D., \& Kertopati, B. (2014). Analisa Pembentukan Portofolio dengan Menggunakan Model Markowitz dan Single Index Model pada Saham LQ 45 di Bursa Efek indonesia Tahun 2009-2013. Finance and Banking Journal, 16(2), 1-17.

Zubir, Z. (2011). Manajemen Portofolio: Penerapannya dalam Investasi Saham. Jakarta: Salemba Empat. 